Check for updates

Cite this: RSC Adv., 2018, 8, 32102

Received 18th July 2018

Accepted 5th September 2018

DOI: $10.1039 / c 8 r a 06100 a$

rsc.li/rsc-advances

\section{Ammonia decomposition over Ni catalysts supported on perovskite-type oxides for the on-site generation of hydrogen $\uparrow$}

\author{
Kaname Okura, Kazunari Miyazaki, Hiroki Muroyama, (D)* Toshiaki Matsui (DD \\ and Koichi Eguchi*
}

Ammonia decomposition has attracted increasing attention as a promising process for the on-site generation of hydrogen. In this study, $\mathrm{Ni}$ catalysts supported on perovskite-type oxides $\left(\mathrm{ABO}_{3}\right)$ were prepared and the activity for ammonia decomposition was examined. The $\mathrm{Ni} / \mathrm{ANbO}_{3}(\mathrm{~A}=\mathrm{Na}$ and $\mathrm{K})$ and $\mathrm{Ni} / \mathrm{AEMnO}_{3}(\mathrm{AE}=\mathrm{Ca}$, Sr, and $\mathrm{Ba})$ catalysts were less effective for this reaction. Meanwhile, the Ni/REAlO 3 $(\mathrm{RE}=\mathrm{La}, \mathrm{Sm}$, and $\mathrm{Gd})$ catalysts exhibited relatively high activity. For $\mathrm{Ni} / \mathrm{AETiO}_{3}$ and $\mathrm{Ni} / \mathrm{AEZrO}$, the performance strongly depended on the A-site element of the perovskite-type oxides, and the $\mathrm{Sr}$ and $\mathrm{Ba}$ elements were more effective than the $\mathrm{Ca}$ one in the respective series. The catalytic activity for $\mathrm{Ni} /$ $\mathrm{AEZrO}_{3}$ was higher than $\mathrm{Ni} / \mathrm{AETiO}_{3}$ in the case of the same alkaline earth element, and $\mathrm{Ni} / \mathrm{BaZrO}$ was the most active among the samples investigated in this work. For these series, the order in the performance corresponded well with that in the basic property. The nitrogen desorption profiles revealed that the evolution of nitrogen atoms, which is one of the kinetically slow steps, effectively proceeded for $\mathrm{Ni} / \mathrm{SrZrO}_{3}$ and $\mathrm{Ni} / \mathrm{BaZrO}_{3}$ compared with the conventional $\mathrm{Ni}$ catalysts. This promotion effect would be ascribed to the strong basic properties of the $\mathrm{SrZrO}_{3}$ and $\mathrm{BaZrO}_{3}$ supports, resulting in the high activity of $\mathrm{Ni} / \mathrm{SrZrO}_{3}$ and $\mathrm{Ni} / \mathrm{BaZrO}_{3}$ for ammonia decomposition.

\section{Introduction}

Nowadays, the establishment of fuel cell systems is strongly required because of concerns about serious environmental issues and the depletion of fossil fuels. Fuel cells are power generation devices operating without harmful emissions, and their energy conversion efficiency is higher than that of conventional internal-combustion engines. Hydrogen is utilized as a primary fuel source for fuel cells. However, the direct storage and transportation of hydrogen are major obstacles for the commercialization of fuel cells due to its low volumetric density $\left(81.8 \mathrm{~g} \mathrm{~m}^{-3}\right)$ and boiling point $\left(-252.8{ }^{\circ} \mathrm{C}\right)$. Thus, the feasibility of the compounds incorporating hydrogen as a hydrogen storage material has been discussed, and is called as a hydrogen carrier. These carriers can be transported to the consumption area, and reformed or decomposed to generate hydrogen on the spot. ${ }^{1,2}$

Among the candidates for the hydrogen carriers, ammonia has been a subject of attention owing to several interesting features. Ammonia has significantly high gravimetric

Department of Energy and Hydrocarbon Chemistry, Graduate School of Engineering, Kyoto University, Nishikyo-ku, Kyoto 615-8510, Japan. E-mail: eguchi@scl.kyoto-u. ac.jp; muroyama.hiroki.5c@kyoto-u.ac.jp

$\dagger$ Electronic supplementary information (ESI) available. See DOI: 10.1039/c8ra06100a hydrogen density (17.6 wt\%) and energy density $\left(3000 \mathrm{~W} \mathrm{~h} \mathrm{~kg}^{-1}\right)$ as compared with other hydrogen carriers. In addition, the liquefaction of ammonia proceeds under mild conditions $\left(-33.4^{\circ} \mathrm{C}\right.$ at atmospheric pressure or $8.46 \mathrm{~atm}$ at 20 $\left.{ }^{\circ} \mathrm{C}\right)$. Moreover, the hydrogen generation via ammonia decomposition does not emit any $\mathrm{CO}$ and $\mathrm{CO}_{2}$. The produced gas from this reaction is preferable as a fuel for fuel cells operative at low temperatures such as polymer electrolyte fuel cells (PEFCs) since the Pt electrode is readily poisoned by CO. Furthermore, the handling and the infrastructure for ammonia are well established because it is one of the most fundamental industrial chemicals. ${ }^{3-7}$

The ammonia decomposition reaction endothermically proceeds as described in eqn (1). According to thermodynamic calculation, the equilibrium ammonia conversion achieves above $99 \%$ at $400{ }^{\circ} \mathrm{C}$ under a pressure of 1 atm. ${ }^{7}$

$$
\mathrm{NH}_{3} \rightarrow 1 / 2 \mathrm{~N}_{2}+3 / 2 \mathrm{H}_{2} \Delta H^{\circ}=+46 \mathrm{~kJ} \mathrm{~mol}^{-1}
$$

The catalytic ammonia decomposition involves the adsorption of ammonia, the stepwise hydrogen dissociation of adsorbed ammonia, and the desorption of nitrogen and hydrogen. The density functional theory (DFT) calculations and kinetic analysis supposed that the first and second dehydrogenation of ammonia and/or the combinative desorption of nitrogen atoms were the kinetically slow steps. ${ }^{8-13}$ 
The previous studies have demonstrated that various metals $\left(\mathrm{Ru},{ }^{14-28} \mathrm{Ir},{ }^{15} \mathrm{Ni},{ }^{14,15,28-39} \mathrm{Rh},{ }^{14} \mathrm{Pt},{ }^{14} \mathrm{Pd},{ }^{14} \mathrm{Co},{ }^{40-42}\right.$ and $\left.\mathrm{Fe}^{14,43}\right)$, alloys $\left(\mathrm{Mo}-\mathrm{Fe},{ }^{44} \mathrm{Ni}-\mathrm{Fe},{ }^{45}\right.$ and $\left.\mathrm{Ni}-\mathrm{Pt}^{46}\right)$, nitrides $\left(\mathrm{MoN}_{x},{ }^{47-50} \mathrm{FeMoN}_{x},{ }^{49}\right.$ $\mathrm{NiMoN}_{x}{ }^{48,49,51}$ and $\mathrm{CoMoN}_{x}{ }^{\mathbf{4 9 , 5 0 , 5 2 , 5 3}}$ ), and carbides $\left(\mathrm{WC}^{54}\right.$ and $\left.\mathrm{VC}_{x}{ }^{55}\right)$ served as the catalysts for ammonia decomposition. Among them, the Ru metal is widely known as the most active catalyst. Until now, much effort has been devoted for the development of the highly active Ru catalysts. ${ }^{16-28}$ However, the utilization of precious metal catalyst is unfavorable due to its limited availability. Thus, in recent years, the Ni metal has attracted much interest as the alternative catalysts owing to its low cost and the highest activity for ammonia decomposition among non-noble metals. ${ }^{4-7}$

Various materials have been investigated as supports of $\mathrm{Ni}$ catalyst for ammonia decomposition. The supports with high surface area such as mesoporous silica, ${ }^{30} \mathrm{Ce}_{0.8} \mathrm{Zr}_{0.2} \mathrm{O}_{2},{ }^{38}$ and multi-wall carbon nanotube (MWCNT) ${ }^{39}$ were preferable for the Ni-based catalytic system. In our study, the rare-earth oxides were effective as the support materials although their surface areas were significantly small $\left(<10 \mathrm{~m}^{2} \mathrm{~g}^{-1}\right){ }^{36}$ This was because hydrogen, which is well known as the inhibitive species for ammonia decomposition, readily desorbed from the Ni metal supported on these oxide materials. Moreover, the promotion effect of the additive species has been also studied for Ni catalysts. The modification by $\mathrm{Sr}$ and Ba species or rare-earth oxides improved the performance of supported $\mathrm{Ni}$ catalysts. $^{32-35,37}$ Based on these results, the presence of basic components is expected to promote ammonia decomposition over Ni catalysts.

Thus, in this work, we focused on the perovskite-type oxides including alkaline, alkaline earth, and rare-earth elements, and employed them as the support material to develop highly active $\mathrm{Ni}$ catalysts. The perovskite-type oxide is generally expressed as a chemical formula of $\mathrm{ABO}_{3}$, in which two types of sites, A site and $\mathrm{B}$ site, are occupied by cations. These materials are known to exhibit interesting properties as the support of catalysts for various chemical reactions. Wang et al. reported that the $\mathrm{BaZrO}_{3}$-supported $\mathrm{Ru}$ catalyst showed the outstanding performance for ammonia synthesis. ${ }^{56}$ Urasaki et al. showed that the $\mathrm{Ni}$ catalysts supported on the perovskite-type oxides had the superior long-term stability as compared with the conventional catalysts in the steam reforming of hydrocarbons..$^{57,58}$ In this study, the effective species in the perovskite-type oxides for ammonia decomposition were discussed by systematically changing the A-site and B-site elements.

\section{Experimental}

\section{Sample preparation}

The perovskite-type oxides were fabricated by the solid state reaction method or the citric acid complex method. $\mathrm{ANbO}_{3}(\mathrm{~A}=$ $\mathrm{Na}$ and $\mathrm{K})$ and $\mathrm{AETiO}_{3}(\mathrm{AE}=\mathrm{Ca}, \mathrm{Sr}$, and $\mathrm{Ba})$ were prepared by the former method, while $\mathrm{REAlO}_{3}(\mathrm{RE}=\mathrm{La}, \mathrm{Sm}$, and Gd), $\mathrm{AEMnO}_{3}$, and $\mathrm{AEZrO}_{3}$ by the latter one. In the solid state reaction method, the following carbonates or metal oxides were used as the starting materials; $\mathrm{Na}_{2} \mathrm{CO}_{3}, \mathrm{~K}_{2} \mathrm{CO}_{3}, \mathrm{CaCO}_{3}, \mathrm{SrCO}_{3}$, $\mathrm{BaCO}_{3}, \mathrm{Nb}_{2} \mathrm{O}_{5}$ (Wako Pure Chemical Industries, Ltd.), and $\mathrm{TiO}_{2}$ (Sigma-Aldrich, Co.). These compounds were stoichiometrically mixed and ground in ethanol overnight. After the evaporation of ethanol, the obtained powder was calcined at $1100{ }^{\circ} \mathrm{C}$ for $5 \mathrm{~h}$ in air. In the case of the citric acid complex method, the corresponding nitrate salts were employed as the starting compounds; $\mathrm{Ca}\left(\mathrm{NO}_{3}\right)_{2} \cdot 6 \mathrm{H}_{2} \mathrm{O}, \mathrm{Sr}\left(\mathrm{NO}_{3}\right)_{2}, \mathrm{Ba}\left(\mathrm{NO}_{3}\right)_{2}, \mathrm{La}\left(\mathrm{NO}_{3}\right)_{3}$ $\cdot 6 \mathrm{H}_{2} \mathrm{O}, \quad \mathrm{Sm}\left(\mathrm{NO}_{3}\right)_{3} \cdot 6 \mathrm{H}_{2} \mathrm{O}, \quad \mathrm{Gd}\left(\mathrm{NO}_{3}\right)_{3} \cdot 6 \mathrm{H}_{2} \mathrm{O}, \quad \mathrm{Al}\left(\mathrm{NO}_{3}\right)_{3} \cdot 9 \mathrm{H}_{2} \mathrm{O}$, $\mathrm{Mn}\left(\mathrm{NO}_{3}\right)_{2} \cdot 6 \mathrm{H}_{2} \mathrm{O}$, and $\mathrm{ZrO}\left(\mathrm{NO}_{3}\right)_{2} \cdot 2 \mathrm{H}_{2} \mathrm{O}$ (Wako Pure Chemical Industries, Ltd.). The metal nitrates with stoichiometric ratios were dissolved in distilled water and the solution was stirred at ca. $60{ }^{\circ} \mathrm{C}$ for $1 \mathrm{~h}$. Then, citric acid (Wako Pure Chemical Industries, Ltd.) was added to this solution at a 1.5 molar times of total metal cations. Subsequently, the $\mathrm{pH}$ in the solution was adjusted to 8.0 by the $28 \% \mathrm{NH}_{3}$ aqueous solution (Wako Pure Chemical Industries, Ltd.). After the evaporation of water at $90{ }^{\circ} \mathrm{C}$, the precursor was heated at $350{ }^{\circ} \mathrm{C}$ for $3 \mathrm{~h}$. The resulting powder was calcined at $1100{ }^{\circ} \mathrm{C}$ for $5 \mathrm{~h}$ in air.

The supported Ni catalysts were prepared by the impregnation method. As the support material, $\mathrm{Nb}_{2} \mathrm{O}_{5}, \mathrm{TiO}_{2}, \mathrm{Al}_{2} \mathrm{O}_{3}(\mathrm{AKP}$ G-015, Sumitomo Chemical Co., Ltd.), $\mathrm{MnO}_{2}$ (Wako Pure Chemical Industries, Ltd.), $\mathrm{ZrO}_{2}$ (Sigma-Aldrich, Co.), and the prepared perovskite-type oxides were used. $\mathrm{Ni}\left(\mathrm{NO}_{3}\right)_{2} \cdot 6 \mathrm{H}_{2} \mathrm{O}$ (Wako Pure Chemical Industries, Ltd.) was employed as a nickel source. The nickel nitrate was dissolved in the distilled water and mixed with the support oxide. After the nickel nitrate solution was evaporated on a steam bath at $80{ }^{\circ} \mathrm{C}$, the obtained precursor was calcined at $600{ }^{\circ} \mathrm{C}$ for $5 \mathrm{~h}$ in air. The Ni metal loading was fixed at $40 \mathrm{wt} \%$.

\section{Characterization}

X-ray diffraction (XRD) measurement was carried out for the ascalcined and reduced catalysts on X-ray diffractometer (Rigaku, Ultima IV) at a setting of $40 \mathrm{kV}$ and $40 \mathrm{~mA}$ with a scanning rate of $2^{\circ} \mathrm{min}^{-1}$. The BET surface area of the support materials was examined by $\mathrm{N}_{2}$ physisorption at $-196{ }^{\circ} \mathrm{C}$ (BEL Japan, BellsorpminiII). Before the measurement, the samples were treated at $300{ }^{\circ} \mathrm{C}$ for $30 \mathrm{~min}$ under vacuum. The Ni surface area was estimated by the CO pulse measurement (BEL Japan, BELCATB) based on the assumption that CO molecules adsorbed on $\mathrm{Ni}$ surface atoms in a ratio of $1: 1$. Prior to the CO adsorption, the catalysts were reduced at $600{ }^{\circ} \mathrm{C}$ for $2 \mathrm{~h}$. To clarify the basic property of the $\mathrm{Ni}$ catalysts, the $\mathrm{CO}_{2}$ temperature-programmed desorption $\left(\mathrm{CO}_{2}\right.$-TPD) measurement was performed (BEL Japan, BELCAT-B). The catalyst was pretreated in pure $\mathrm{O}_{2}$ at $800{ }^{\circ} \mathrm{C}$ for $1 \mathrm{~h}$, and subsequently in pure $\mathrm{H}_{2}$ at the same temperature for $2 \mathrm{~h}$. After the exposure to $\mathrm{CO}_{2}$ at $50{ }^{\circ} \mathrm{C}$ for $1 \mathrm{~h}$, the samples were heated in the He flow at a heating rate of

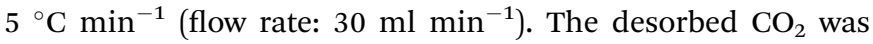
confirmed by a thermal conductive detector (TCD). To discuss the desorption process of nitrogen in ammonia decomposition, the ammonia temperature-programmed surface reaction $\left(\mathrm{NH}_{3}\right.$ TPSR) measurement was carried out (BEL Japan, BELCAT-A). The pretreatment condition was the same as that in the $\mathrm{CO}_{2}$ TPD measurement except for the reactant adsorption step. Ammonia was supplied at $50{ }^{\circ} \mathrm{C}$ for $1 \mathrm{~h}$, followed by the gas replacement by Ar for $5 \mathrm{~h}$. The desorption behavior of $\mathrm{N}_{2}$ in a heating process at a rate of $5{ }^{\circ} \mathrm{C} \mathrm{min}^{-1}$ in $\mathrm{Ar}$ (flow rate: 30 
$\mathrm{ml} \min ^{-1}$ ) was monitored by an on-line mass spectrometer (Pfeiffer Vacuum, OmniStar GSD320).

The Ni particle size distribution and the morphology were examined by a transmission electron microscope (TEM, JEM$2100 \mathrm{~F}, \mathrm{JEOL}$ ) equipped with an energy dispersive X-ray spectrometer (EDS, JED-2300T, JEOL). Prior to the analysis, the Ni catalysts were reduced at $600{ }^{\circ} \mathrm{C}$ for $2 \mathrm{~h}$ in $50 \% \mathrm{H}_{2} / \mathrm{Ar}$. The average Ni particle size of each sample was estimated from 150180 particles.

\section{Catalytic activity}

The catalytic ammonia decomposition reaction was performed in a fixed-bed flow reactor. The catalyst (10-18 mesh, $300 \mathrm{mg}$ ) was placed in the center of quartz tube, and reduced at $600{ }^{\circ} \mathrm{C}$ for $2 \mathrm{~h}$ in $50 \% \mathrm{H}_{2} / \mathrm{Ar}$ (flow rate: $80 \mathrm{ml} \mathrm{min}^{-1}$ ). After the cooling down to $350{ }^{\circ} \mathrm{C}$ in $\mathrm{Ar}$, pure $\mathrm{NH}_{3}$ was supplied at the weight/flow $(W / F)$ ratio of $0.60 \mathrm{~g} \mathrm{~s} \mathrm{~cm}^{-3}$ under an atmospheric pressure. The catalytic activity was evaluated in a heating process. The stability test was carried out for $35 \mathrm{~h}$ at $550{ }^{\circ} \mathrm{C}$ and $W / F=0.18 \mathrm{~g}$ s $\mathrm{cm}^{-3}$. The flow rate of outlet gas was measured by a soap-film flow meter (HORIBA STEC) after removing unconverted ammonia by diluted sulfuric acid. The conversion of ammonia was calculated by the following equation with an assumption that the ratio of produced nitrogen to hydrogen was $1: 3$.

$$
\mathrm{NH}_{3} \text { conversion } / \%=\left(F_{\text {out }} / 2 F_{\text {in }}\right) \times 100
$$

where $F_{\text {in }}$ and $F_{\text {out }}$ are the flow rates of inlet ammonia gas and outlet hydrogen and nitrogen gases, respectively.

\section{Results and discussion}

\section{Perovskite-type oxide support}

The crystal structure of the Ni catalysts supported on the perovskite-type oxide was examined by XRD analysis. As the representative samples in each system, the XRD patterns of the as-calcined and reduced $\mathrm{Ni} / \mathrm{NaNbO}_{3}, \mathrm{Ni} / \mathrm{LaAlO}_{3}, \mathrm{Ni} / \mathrm{CaMnO}_{3}$, $\mathrm{Ni} / \mathrm{SrTiO}_{3}$, and $\mathrm{Ni} / \mathrm{BaZrO}_{3}$ catalysts are shown in Fig. 1(a) and (b), respectively. For the as-calcined Ni catalysts, the characteristic peaks assigned to the phases of the corresponding support oxide and nickel oxide were confirmed. After the reduction treatment at $600{ }^{\circ} \mathrm{C}$, nickel oxide was changed to metallic nickel. As for the perovskite-type oxides, $\mathrm{NaNbO}_{3}$, $\mathrm{LaAlO}_{3}, \mathrm{SrTiO}_{3}$, and $\mathrm{BaZrO}_{3}$ were stable under the reducing atmosphere, while $\mathrm{CaMnO}_{3}$ decomposed to various compounds. The similar tendency was observed in the XRD patterns of the other $\mathrm{Ni} / \mathrm{ANbO}_{3}, \mathrm{Ni} / \mathrm{REAlO}_{3}, \mathrm{Ni} / \mathrm{AEMnO}_{3}, \mathrm{Ni}$ / $\mathrm{AETiO}_{3}$, and $\mathrm{Ni} / \mathrm{AEZrO}_{3}$ catalysts (see Fig. S1 and S2 in ESI $\dagger$ ). This result suggests that the $\mathrm{AEMnO}_{3}$ oxides were inappropriate as the support material for ammonia decomposition.

The physical properties of the Ni catalysts were studied. Table 1 summarizes the BET surface area of each support oxide determined by $\mathrm{N}_{2}$ adsorption/desorption measurement. The specific surface area of all the perovskite-type oxides was considerably small $\left(<10 \mathrm{~m}^{2} \mathrm{~g}^{-1}\right)$ probably because the sintering of support material remarkably proceeded during the calcination at $1100{ }^{\circ} \mathrm{C}$ in the preparation step. The support with small (a) After calcination

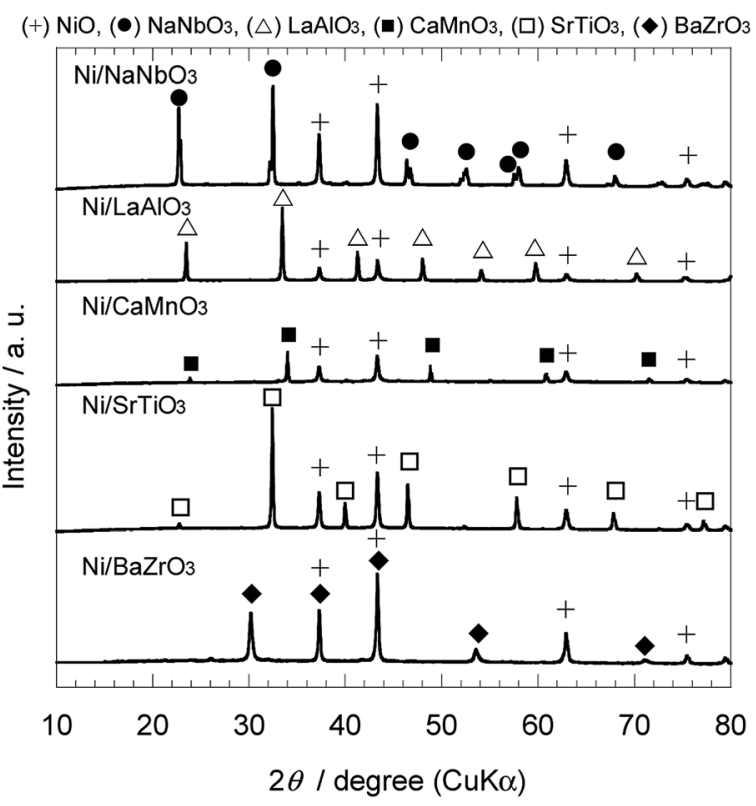

(b) After reduction

$(\boldsymbol{x}) \mathrm{Ni},(\bullet) \mathrm{NaNbO}_{3},(\Delta) \mathrm{LaAlO}_{3},(\Delta) \mathrm{Ca}_{3} \mathrm{Mn}_{2} \mathrm{O}_{7},(\boldsymbol{v}) \mathrm{CaMn}_{4} \mathrm{O}_{7}$, $(\nabla) \mathrm{CaCO}_{3},(\square) \mathrm{SrTiO}_{3},(\diamond) \mathrm{BaZrO}_{3}$

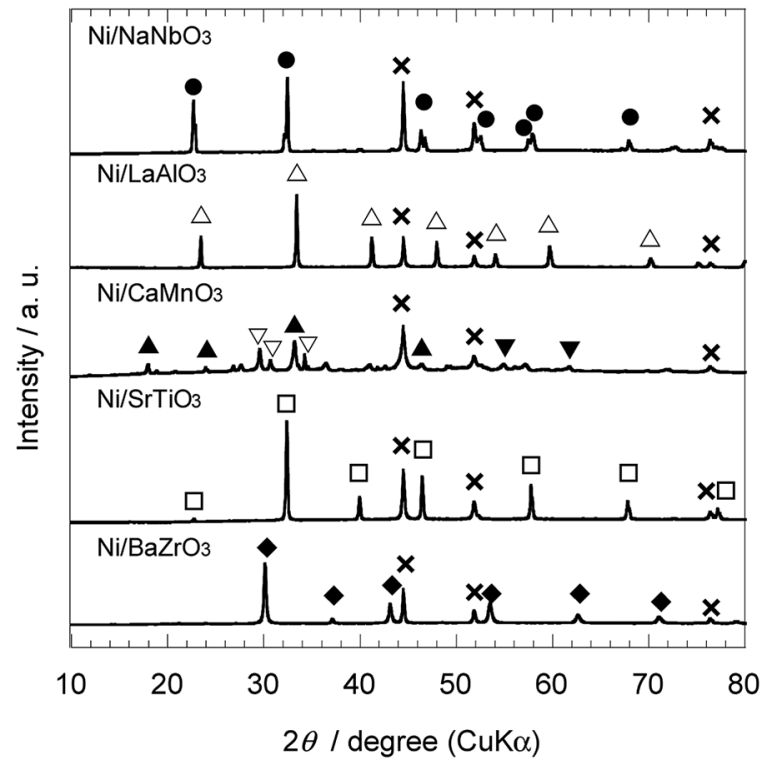

Fig. 1 XRD patterns of 40 wt\% Ni/NaNbO $3, \mathrm{Ni} / \mathrm{LaAlO}_{3}, \mathrm{Ni} / \mathrm{CaMnO}_{3}, \mathrm{Ni} /$ $\mathrm{SrTiO}_{3}$, and $\mathrm{Ni} / \mathrm{BaZrO}_{3}$ (a) after calcination at $600{ }^{\circ} \mathrm{C}$ and (b) after subsequent reduction at $600^{\circ} \mathrm{C}$.

surface area should lead to the low dispersion of Ni particles. Actually, in most of the prepared Ni catalysts, the Ni surface area estimated by the CO pulse chemisorption measurement was significantly low (see Table 1). This suggests that the Ni particle size for these samples was highly large. Besides, the inhibition of $\mathrm{CO}$ adsorption on $\mathrm{Ni}$ metal by the strong metal-support interaction (SMSI) effect would be partly responsible for this result. ${ }^{59}$ For example, it has been reported that $\mathrm{BaTiO}_{3}$ and $\mathrm{BaZrO}_{3}$ were the SMSI oxides. ${ }^{56,60}$ 
Table 1 Physical properties for Ni catalysts supported on various oxides

\begin{tabular}{lcc}
\hline Catalyst & Support surface area ${ }^{a}\left(\mathrm{~m}^{2} \mathrm{~g}_{\text {sample }}{ }^{-1}\right)$ & Ni surface area ${ }^{b}\left(\mathrm{~m}^{2} \mathrm{~g}_{\text {sample }}{ }^{-1}\right)$ \\
\hline $\mathrm{Ni} / \mathrm{Nb}_{2} \mathrm{O}_{5}$ & 7.4 & Trace \\
$\mathrm{Ni} / \mathrm{NaNbO}_{3}$ & 4.1 & Trace \\
$\mathrm{Ni} / \mathrm{KNbO}_{3}$ & 8.4 & Trace \\
$\mathrm{Ni} / \mathrm{Al}_{2} \mathrm{O}_{3}$ & 130 & 4.9 \\
$\mathrm{Ni} / \mathrm{LaAlO}_{3}$ & 9.9 & 0.83 \\
$\mathrm{Ni} / \mathrm{SmAlO}_{3}$ & 8.1 & 1.4 \\
$\mathrm{Ni} / \mathrm{GdAlO}_{3}$ & 4.6 & 1.3 \\
$\mathrm{Ni} / \mathrm{MnO}_{2}$ & 2.4 & Trace \\
$\mathrm{Ni} / \mathrm{CaMnO}_{3}$ & 6.6 & Trace \\
$\mathrm{Ni} / \mathrm{SrMnO}_{3}$ & 7.9 & Trace \\
$\mathrm{Ni} / \mathrm{BaMnO}_{3}$ & 7.2 & Trace \\
$\mathrm{Ni} / \mathrm{TiO}_{2}$ & 12 & Trace \\
$\mathrm{Ni} / \mathrm{CaTiO}_{3}$ & 6.5 & Trace \\
$\mathrm{Ni} / \mathrm{SrTiO}_{3}$ & 5.5 & Trace \\
$\mathrm{Ni} / \mathrm{BaTiO}_{3}$ & 4.9 & Trace \\
$\mathrm{Ni} / \mathrm{ZrO}_{2}$ & 15 & Trace \\
$\mathrm{Ni} / \mathrm{CaZrO}_{3}$ & 6.0 & Trace \\
$\mathrm{Ni} / \mathrm{SrZrO}_{3}$ & 6.1 & Trace \\
$\mathrm{Ni} / \mathrm{BaZrO}_{3}$ & 7.4 & Trace
\end{tabular}

\section{Catalytic activity}

Fig. 2 depicts the ammonia conversion at $550{ }^{\circ} \mathrm{C}$ for the $\mathrm{Ni}$ catalysts prepared in this study. In the $\mathrm{Ni} /$ niobate series, the performances of $\mathrm{Ni} / \mathrm{Nb}_{2} \mathrm{O}_{5}, \mathrm{Ni} / \mathrm{NaNbO}_{3}$, and $\mathrm{Ni} / \mathrm{KNbO}_{3}$ were almost the same. Among the samples investigated, the conversions for these catalysts were considerably low. The $\mathrm{Ni} / \mathrm{REAlO}_{3}$ catalysts exhibited relatively high activity, and were more active than the $\mathrm{Ni} / \mathrm{Al}_{2} \mathrm{O}_{3}$ catalyst. As reported in the previous literatures, ${ }^{32-36}$ the presence of rare-earth elements led to the enhancement of performance for ammonia decomposition. The activity of $\mathrm{Ni} / \mathrm{REAlO}_{3}$ was scarcely affected depending on the rare-earth element. The conversions of $\mathrm{Ni} / \mathrm{AEMnO}_{3}$ were higher than those of $\mathrm{Ni} / \mathrm{ANbO}_{3}$, while lower than those of $\mathrm{Ni} / \mathrm{REAlO}_{3}$.

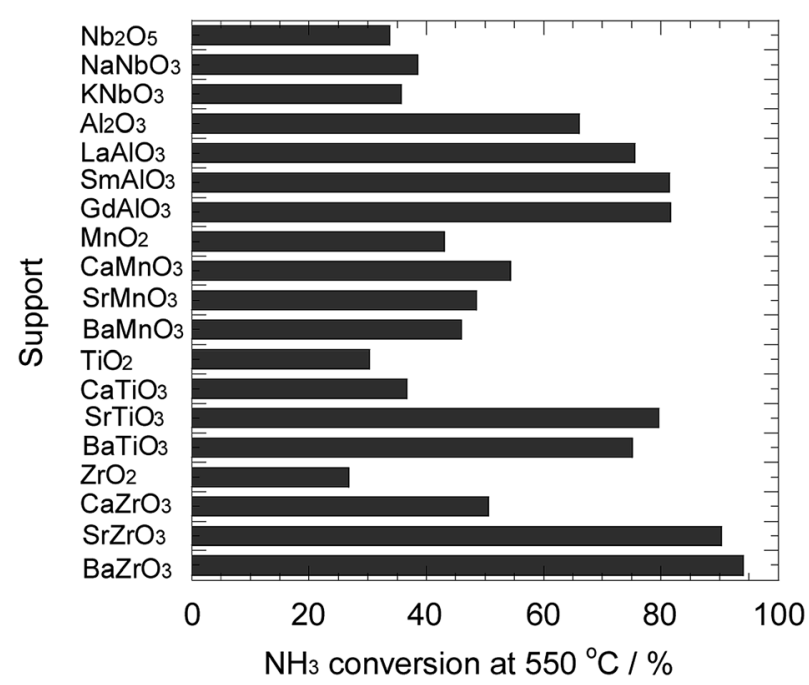

Fig. 2 Ammonia conversion for ammonia decomposition at $550{ }^{\circ} \mathrm{C}$ for the $\mathrm{Ni}$ catalysts supported on various oxides. Reaction condition; $\mathrm{NH}_{3}: 100$ vol\%, W/F $=0.60 \mathrm{~g} \mathrm{~s} \mathrm{~cm}^{-3}$.
As mentioned in Fig. 1, the $\mathrm{AEMnO}_{3}$ oxides decomposed to various species under the reducing atmosphere. A collapse of the support structure would give rise to the sintering of the loaded metal. Additionally, a part of the $\mathrm{Ni} / \mathrm{AETiO}_{3}$ and $\mathrm{Ni}$ / $\mathrm{AEZrO}_{3}$, their performances strongly depended on the A-site element of the perovskite-type oxides. In series, the $\mathrm{Sr}$ and $\mathrm{Ba}$ elements were more effective than the $\mathrm{Ca}$ one. Hereafter, the support effect of $\mathrm{AETiO}_{3}$ and $\mathrm{AEZrO}_{3}$ was discussed in detail.

\section{$\mathrm{Ni} /$ titanate and $\mathrm{Ni} /$ zirconate}

As mentioned above, the support effect of $\mathrm{AETiO}_{3}$ and $\mathrm{AEZrO}_{3}$ depended on the alkaline earth element of the perovskite-type oxides. The temperature dependencies of ammonia conversion for the $\mathrm{Ni} /$ titanate and $\mathrm{Ni} /$ zirconate series are indicated in Fig. 3 and 4 , respectively. The decomposition reaction started from $c a .350{ }^{\circ} \mathrm{C}$ and the ammonia conversion increased with a rise in reaction temperature. In the $\mathrm{Ni}$ /titanate series, $\mathrm{Ni}$ / $\mathrm{SrTiO}_{3}$ and $\mathrm{Ni} / \mathrm{BaTiO}_{3}$ were more active than $\mathrm{Ni} / \mathrm{TiO}_{2}$ and $\mathrm{Ni}$ / $\mathrm{CaTiO}_{3}$, and the reaction almost completed at $c a .600{ }^{\circ} \mathrm{C}$ over the former catalysts. On the other hand, in the case of the $\mathrm{Ni}$ / zirconate catalysts, the order of the performance in this temperature range was as follows; $\mathrm{Ni} / \mathrm{BaZrO}_{3}>\mathrm{Ni} / \mathrm{SrZrO}_{3}>\mathrm{Ni}$ / $\mathrm{CaZrO}_{3}>\mathrm{Ni} / \mathrm{ZrO}_{2}$. The behavior of activity against the difference in the alkaline earth element was similar in both series; the $\mathrm{Sr}$ and $\mathrm{Ba}$ species were more preferable as the constituent elements of support material. Besides, the $\mathrm{Ni} / \mathrm{AEZrO}_{3}$ catalysts exhibited higher ammonia conversion than the $\mathrm{Ni} / \mathrm{AETiO}_{3}$ ones for the same $\mathrm{AE}$ element, and the $\mathrm{Ni} / \mathrm{BaZrO}_{3}$ catalyst was the most active in this work. As for $\mathrm{Ni} / \mathrm{BaZrO}_{3}$, the catalytic stability was studied at $550{ }^{\circ} \mathrm{C}$ and $W / F=0.18 \mathrm{~g} \mathrm{~s} \mathrm{~cm}^{-3}$. As shown in Fig. 5, the ammonia conversion at this reaction condition was ca. $62 \%$ and remained unchanged over $30 \mathrm{~h}$. This result clarified that the $\mathrm{Ni} / \mathrm{BaZrO}_{3}$ catalyst was highly stable. 


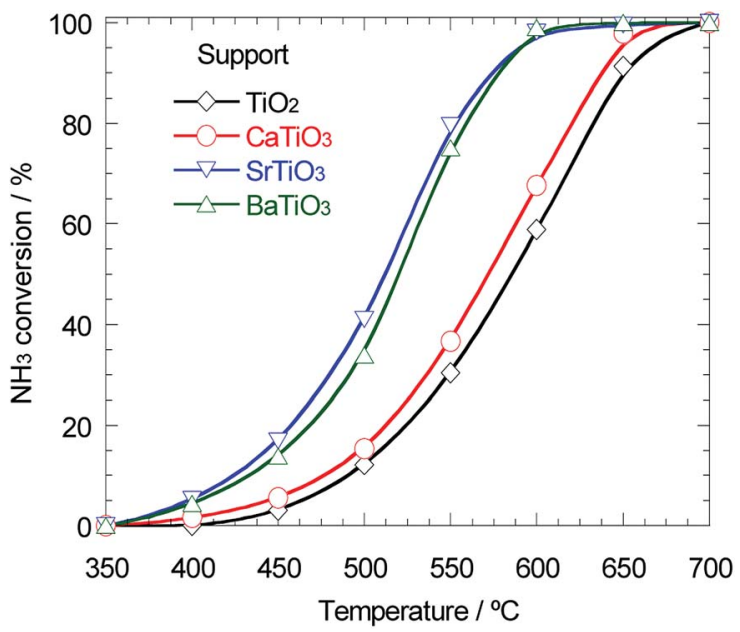

Fig. 3 Ammonia conversion for ammonia decomposition against reaction temperature over $40 \mathrm{wt} \% \mathrm{Ni} / \mathrm{TiO}_{2}, \mathrm{Ni} / \mathrm{CaTiO}, \mathrm{Ni} / \mathrm{SrTiO}_{3}$, and $\mathrm{Ni} / \mathrm{BaTiO}_{3}$. Reaction condition; $\mathrm{NH}_{3}: 100$ vol\%, W/F $=0.60 \mathrm{~g} \mathrm{~s} \mathrm{~cm}^{-3}$.

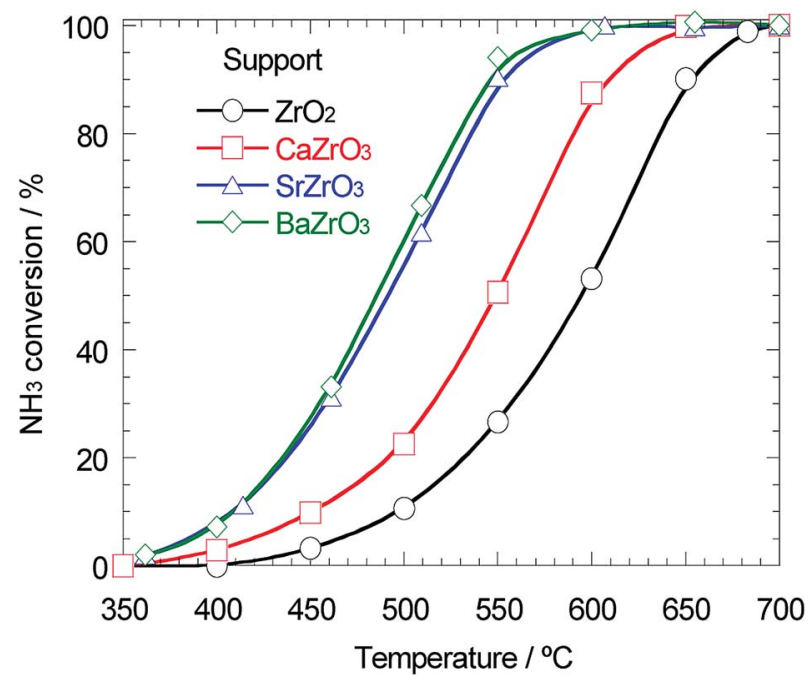

Fig. 4 Ammonia conversion for ammonia decomposition against reaction temperature over $40 \mathrm{wt} \% \mathrm{Ni} / \mathrm{ZrO}_{2}, \mathrm{Ni} / \mathrm{CaZrO}{ }_{3}, \mathrm{Ni} / \mathrm{SrZrO}_{3}$, and $\mathrm{Ni} / \mathrm{BaZrO}_{3}$. Reaction condition; $\mathrm{NH}_{3}: 100$ vol\%, W/F $=0.60 \mathrm{~g} \mathrm{~s} \mathrm{~cm}^{-3}$.

The microstructure and the average Ni particle size of the $\mathrm{Ni} /$ $\mathrm{AEZrO}_{3}$ series were examined by TEM observation to evaluate the influence of alkaline earth element on the morphology of catalysts. Fig. 6 illustrates the TEM images and the Ni particle size distributions for $\mathrm{Ni} / \mathrm{ZrO}_{2}, \mathrm{Ni} / \mathrm{CaZrO}_{3}, \mathrm{Ni} / \mathrm{SrZrO}_{3}$, and $\mathrm{Ni}$ / $\mathrm{BaZrO}_{3}$ after the reduction at $600{ }^{\circ} \mathrm{C}$. For comparison, the result of $\mathrm{Ni} / \mathrm{Al}_{2} \mathrm{O}_{3}$ is also depicted. It is expected that the $\mathrm{Ni}$ dispersion for $\mathrm{Ni} / \mathrm{Al}_{2} \mathrm{O}_{3}$ is relatively high judging from the large Ni surface area as listed in Table 1 . In all the images, some Ni particles are indicated by white arrows based on the result of EDS analysis. The enormous particles ( $>c a .1000 \mathrm{~nm}$ ) observed in the $\mathrm{Ni}$ / zirconate series were assigned to the support oxides. The average $\mathrm{Ni}$ particle size was $37.4 \mathrm{~nm}$ for $\mathrm{Ni} / \mathrm{ZrO}_{2}$. The $\mathrm{Ni} / \mathrm{CaZrO}_{3}$ and $\mathrm{Ni} / \mathrm{SrZrO}_{3}$ catalysts had larger Ni particles as compared with $\mathrm{Ni} / \mathrm{ZrO}_{2}$, and the average $\mathrm{Ni}$ size was $48.4 \mathrm{~nm}$ and $57.6 \mathrm{~nm}$,

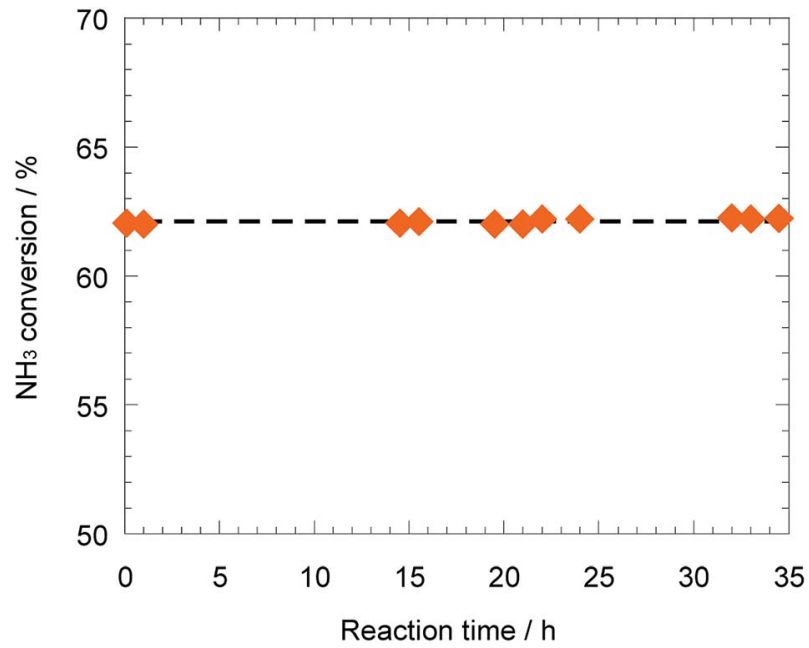

Fig. 5 Stability test over $40 \mathrm{wt} \% \mathrm{Ni} / \mathrm{BaZrO}_{3}$ at $550{ }^{\circ} \mathrm{C}$. Reaction condition; $\mathrm{NH}_{3}: 100$ vol\%, W/F $=0.18 \mathrm{~g} \mathrm{~s} \mathrm{~cm}^{-3}$.

respectively. In the case of $\mathrm{Ni} / \mathrm{BaZrO}_{3}$, the ratio of $\mathrm{Ni}$ particles above $100 \mathrm{~nm}$ was high, and the average Ni particle size was $99.2 \mathrm{~nm}$. In comparison with $\mathrm{Ni} / \mathrm{Al}_{2} \mathrm{O}_{3}$ (average $\mathrm{Ni}$ size; 23.7 $\mathrm{nm}$ ), the $\mathrm{Ni}$ particles for the $\mathrm{Ni} / \mathrm{AEZrO}_{3}$ catalysts were significantly larger and the particle size distribution range was wider regardless of alkaline earth elements in the perovskite-type oxides. These results implied that the $\mathrm{AEZrO}_{3}$ supports were ineffective for the dispersion of $\mathrm{Ni}$ particles, leading to the smaller Ni surface area. These dispersion states should be ascribed to the small surface area of the zirconate supports. Considering that $\mathrm{Ni} / \mathrm{SrZrO}_{3}$ and $\mathrm{Ni} / \mathrm{BaZrO}_{3}$ were highly active, these supports would remarkably enhance the turnover frequency (TOF). Although the Ni surface and/or Ni/support material interface serve as the reaction sites in ammonia decomposition, in this catalyst system the differences in the activity could not be explained in terms of the size and surface area of Ni particle. Thus, the chemical properties of support surface and the electronic state of nickel species could be expected to affect the catalytic activity.

Next, the basic property of the $\mathrm{Ni} / \mathrm{AETiO}_{3}$ and $\mathrm{Ni} / \mathrm{AEZrO}_{3}$ catalysts was evaluated by the $\mathrm{CO}_{2}$-TPD measurement since it is known that the catalysts with the strong basic sites promote ammonia decomposition. ${ }^{19}$ Fig. 7 describes the $\mathrm{CO}_{2}$ desorption profiles for the samples reduced at $800{ }^{\circ} \mathrm{C}$. In the $\mathrm{Ni} / \mathrm{AETiO}_{3}$ series, the $\mathrm{CO}_{2}$ desorption peak initiated from $\mathrm{ca} .50{ }^{\circ} \mathrm{C}$ and the peak shape was similar to each other. On the other hand, the evolution of $\mathrm{CO}_{2}$ was detected at relatively high temperatures for $\mathrm{Ni} / \mathrm{AEZrO}_{3}$ as compared with $\mathrm{Ni} / \mathrm{AETiO}_{3}$ at the same A-site element. This means that the basic property of $\mathrm{Ni} / \mathrm{AEZrO}_{3}$ was stronger than that of $\mathrm{Ni} / \mathrm{AETiO}_{3}$. In particular, $\mathrm{Ni} / \mathrm{SrZrO}_{3}$ and $\mathrm{Ni}$ / $\mathrm{BaZrO}_{3}$ should possess highly strong basic sites judging from the desorption above $700{ }^{\circ} \mathrm{C}$. The $\mathrm{CO}_{2}$ desorption amount per the sample weight in the range of $50-800{ }^{\circ} \mathrm{C}$ is presented in

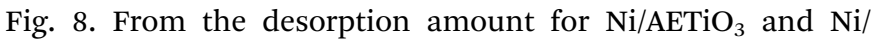
$\mathrm{AEZrO}_{3}$ in the case of the same A-site element, the amount of basic sites was larger for the latter series. The electronegativity of $\mathrm{Zr}$ smaller than that of Ti might be one of the reasons for this 
(a) $\mathrm{Ni} / \mathrm{ZrO}$
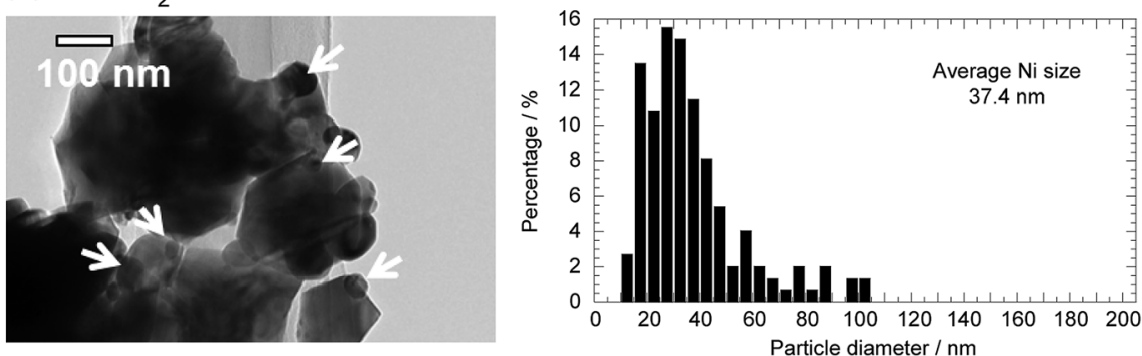

(b) $\mathrm{Ni} / \mathrm{CaZrO}$
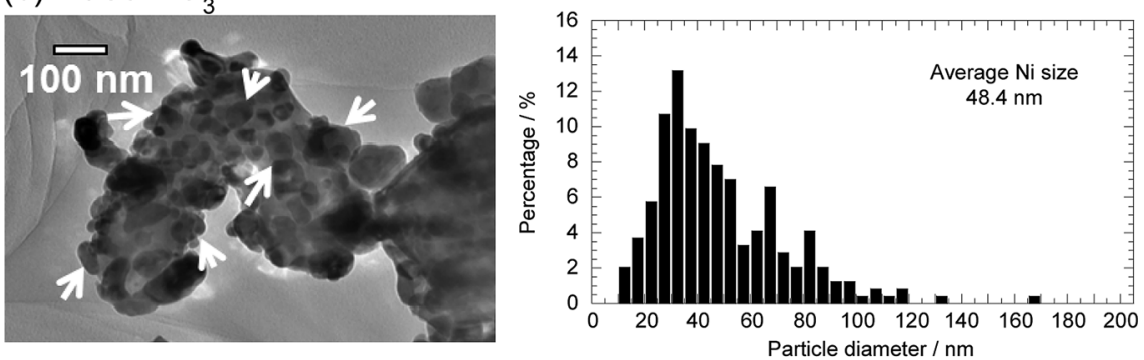

(c) $\mathrm{Ni} / \mathrm{SrZrO}_{3}$
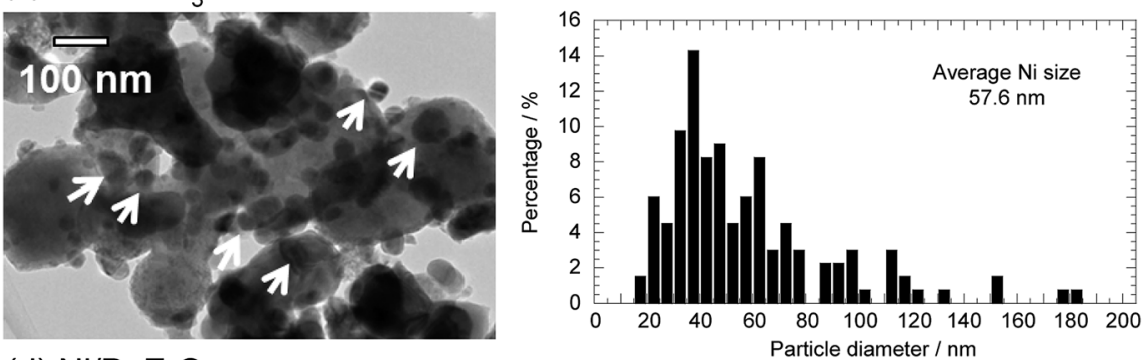

(d) $\mathrm{Ni} / \mathrm{BaZrO}_{3}$
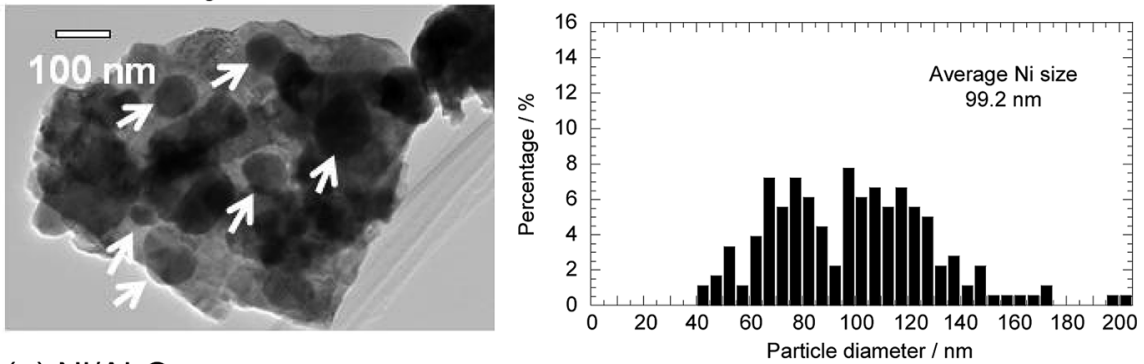

(e) $\mathrm{Ni} / \mathrm{Al}_{2} \mathrm{O}_{3}$
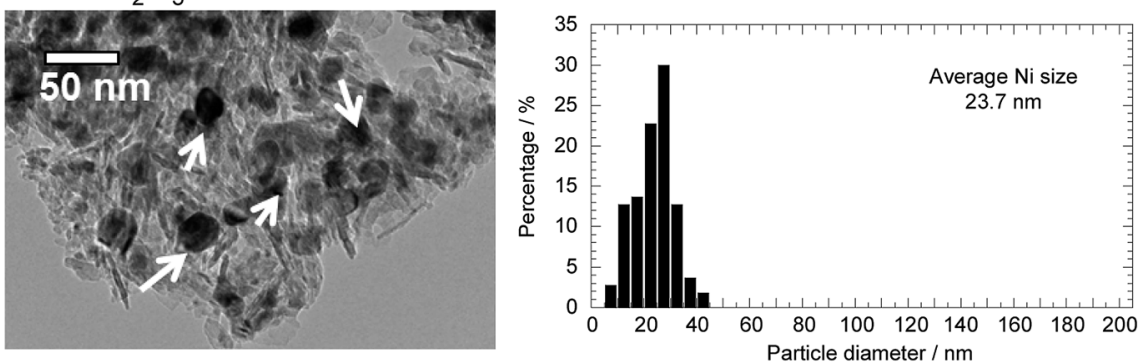

Fig. 6 TEM images and Ni particle size distribution histograms of 40 wt\% (a) $\mathrm{Ni} / \mathrm{ZrO}_{2}$, (b) $\mathrm{Ni} / \mathrm{CaZrO}_{3}$, (c) $\mathrm{Ni} / \mathrm{SrZrO}_{3}$, (d) $\mathrm{Ni} / \mathrm{BaZrO}_{3}$, and (e) $\mathrm{Ni} / \mathrm{Al}_{2} \mathrm{O}_{3}$.

result. Moreover, when the B-site element was fixed, the $\mathrm{CO}_{2}$ desorption amount was larger for the $\mathrm{Sr}$ and $\mathrm{Ba}$ species than the $\mathrm{Ca}$ one in both series. This result indicated that the $\mathrm{Sr}$ or Ba components were more preferable for an increase in the basic sites. The catalytic test for Ni/AETiO ${ }_{3}$ and $\mathrm{Ni} / \mathrm{AEZrO}_{3}$ (see Fig. 24) revealed that the latter sample was more active for the same
$\mathrm{AE}$ element, and that the Sr and Ba species were more effective than the Ca species in the respective series. This trend corresponded to that of basic property in $\mathrm{Ni} / \mathrm{AETiO}_{3}$ and $\mathrm{Ni} / \mathrm{AEZrO}_{3}$. Therefore, the strong basic property of the perovskite-type oxide would be responsible for the high catalytic activity for ammonia decomposition. 


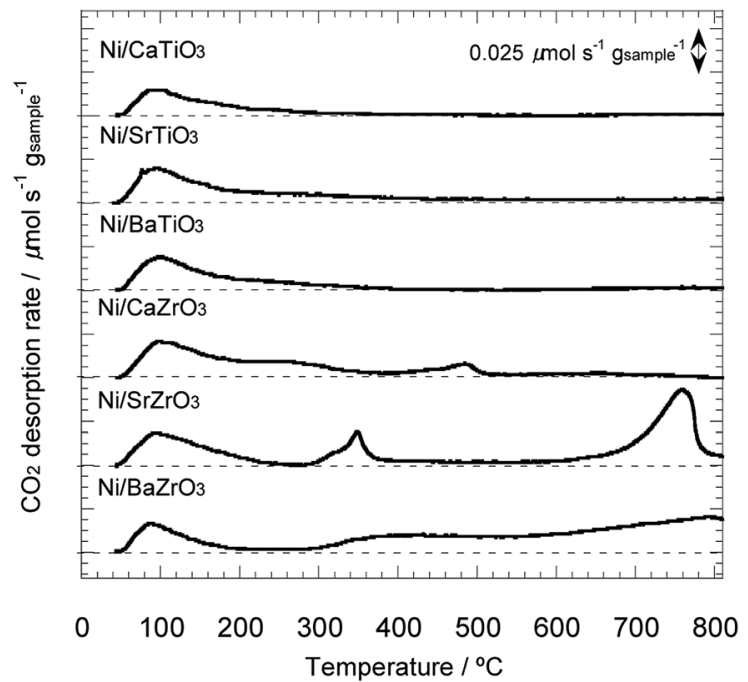

Fig. $7 \mathrm{CO}_{2}-\mathrm{TPD}$ profiles for 40 wt\% $\mathrm{Ni} / \mathrm{CaTiO}, \mathrm{Ni} / \mathrm{SrTiO}_{3}, \mathrm{Ni} / \mathrm{BaTiO}$, $\mathrm{Ni} / \mathrm{CaZrO}_{3}, \mathrm{Ni} / \mathrm{SrZrO}_{3}$, and $\mathrm{Ni} / \mathrm{BaZrO}_{3}$ in $\mathrm{He}$ under a heating rate of $5^{\circ} \mathrm{C} \mathrm{min}^{-1}$.

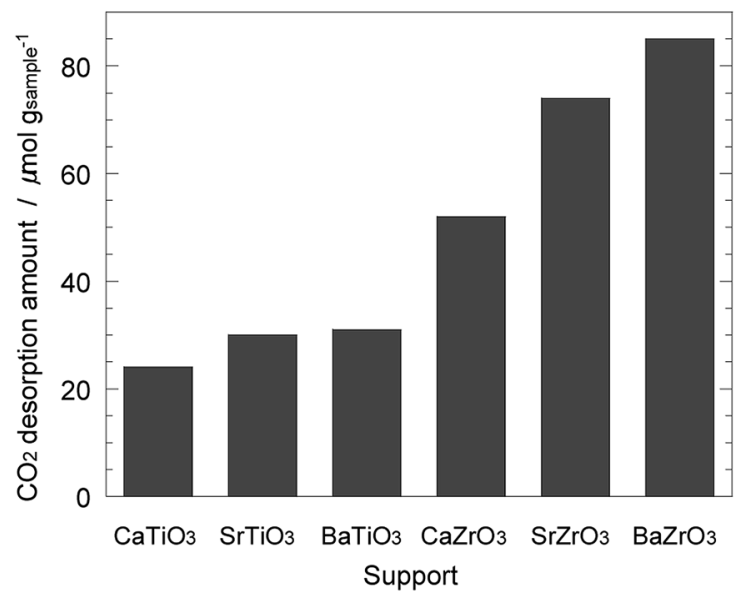

Fig. $8 \mathrm{CO}_{2}$ desorption amount in the range of $50-800^{\circ} \mathrm{C}$ obtained by $\mathrm{CO}_{2}-\mathrm{TPD}$ measurement in Fig. 7 for 40 wt\% $\mathrm{Ni} / \mathrm{CaTiO}_{3}, \mathrm{Ni} / \mathrm{SrTiO}_{3}, \mathrm{Ni} /$ $\mathrm{BaTiO}_{3}, \mathrm{Ni} / \mathrm{CaZrO}_{3}, \mathrm{Ni} / \mathrm{SrZrO}_{3}$, and $\mathrm{Ni} / \mathrm{BaZrO}_{3}$

In previous literatures, the electron donation from the additive or support to the active metal promoted the nitrogen desorption step, which is kinetically slow. ${ }^{19,37,61}$ Thus, the $\mathrm{NH}_{3}-$ TPSR measurement was carried out to discuss the nitrogen desorption behavior for the $\mathrm{Ni} / \mathrm{AEZrO}_{3}$ series. The $\mathrm{NH}_{3}$ adsorption was conducted at $50{ }^{\circ} \mathrm{C}$. Fig. 9 shows the nitrogen $(m / z=28)$ desorption behavior for the $\mathrm{Ni} / \mathrm{ZrO}_{2}$ and $\mathrm{Ni} / \mathrm{AEZrO}_{3}$ catalysts. In the case of $\mathrm{Ni} / \mathrm{ZrO}_{2}$, which was low active for ammonia decomposition, the nitrogen desorption was confirmed above $\mathrm{ca} .500{ }^{\circ} \mathrm{C}$. For $\mathrm{Ni} / \mathrm{CaZrO}_{3}$, the desorption initiated at $c a .180{ }^{\circ} \mathrm{C}$ and continuously proceeded even above $600{ }^{\circ} \mathrm{C}$. Considering that the peak area at $c a .550{ }^{\circ} \mathrm{C}$ was large, the ratio of nitrogen atoms strongly-interacting with Ni metal would be relatively high. These desorption temperature range were higher than those for the conventional Ni catalysts supported on alumina or rare-earth oxide, ${ }^{35-37}$ suggesting that $\mathrm{Ni} /$

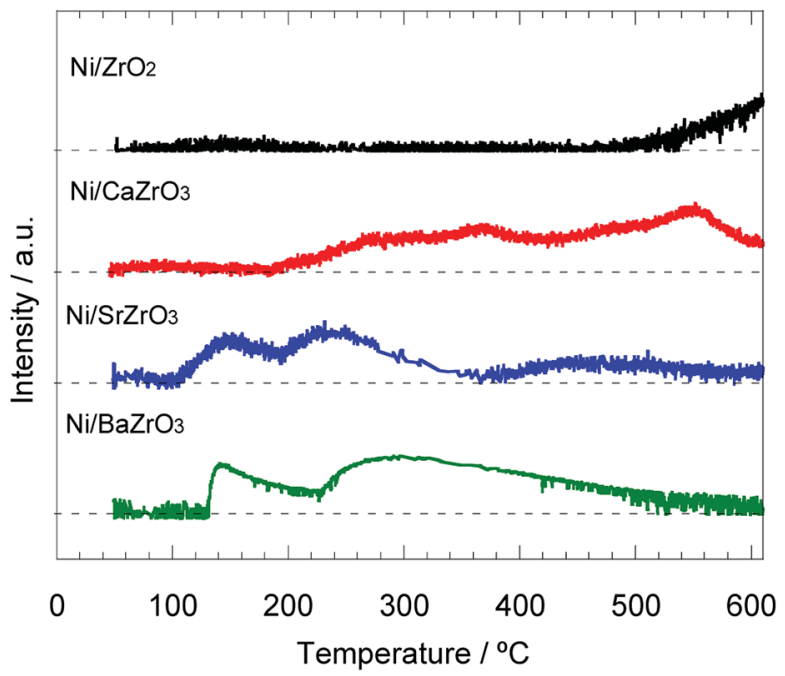

Fig. $9 \mathrm{~N}_{2}$ desorption profiles for $40 \mathrm{wt} \% \mathrm{Ni} / \mathrm{ZrO}_{2}, \mathrm{Ni} / \mathrm{CaZrO} \mathrm{Zr}_{3}, \mathrm{Ni} /$ $\mathrm{SrZrO}_{3}$, and $\mathrm{Ni} / \mathrm{BaZrO}_{3}$ obtained by $\mathrm{NH}_{3}-\mathrm{TPSR}$ measurement in $\mathrm{Ar}$ flow under a heating rate of $5^{\circ} \mathrm{C} \mathrm{min}^{-1}$.

$\mathrm{ZrO}_{2}$ and $\mathrm{Ni} / \mathrm{CaZrO}_{3}$ were ineffective for the nitrogen evolution. On the other hand, in the profiles of $\mathrm{Ni} / \mathrm{SrZrO}_{3}$ and $\mathrm{Ni} / \mathrm{BaZrO}_{3}$, the nitrogen desorption started at $c a .120-130{ }^{\circ} \mathrm{C}$, and terminated at relatively low temperatures as compared with $\mathrm{Ni} / \mathrm{ZrO}_{2}$ and $\mathrm{Ni} / \mathrm{CaZrO}_{3}$. These onset desorption temperatures were significantly low as compared with those of various $\mathrm{Ni}$ catalysts. ${ }^{35-37}$ This result means that the $\mathrm{SrZrO}_{3}$ and $\mathrm{BaZrO}_{3}$ supports were effective for the nitrogen desorption, leading to the higher performance of $\mathrm{Ni} / \mathrm{SrZrO}_{3}$ and $\mathrm{Ni} / \mathrm{BaZrO}_{3}$. Considering that the electron donation from the support to active metal could promote the nitrogen desorption step, ${ }^{61}$ this support effect would be mainly ascribed to the strong basic property of $\mathrm{SrZrO}_{3}$ and $\mathrm{BaZrO}_{3}$.

\section{Conclusions}

The ammonia decomposition was investigated over the $\mathrm{Ni}$ catalysts supported on the perovskite-type oxides. The $\mathrm{Ni} /$ $\mathrm{ANbO}_{3}$ and $\mathrm{Ni} / \mathrm{AEMnO}_{3}$ catalysts were less effective for this reaction, while the $\mathrm{Ni} / \mathrm{REAlO}_{3}$ ones exhibited relatively high activity. For Ni/AETiO 3 and $\mathrm{Ni} / \mathrm{AEZrO}_{3}$, the performance strongly depended on the alkaline earth metal in the perovskitetype oxides, and the $\mathrm{Sr}$ and Ba species were superior to the $\mathrm{Ca}$ species in the respective series. The activity was higher for the $\mathrm{Ni} / \mathrm{AEZrO}_{3}$ catalyst than the $\mathrm{Ni} / \mathrm{AETiO}_{3}$ one in the case of the same $\mathrm{AE}$ element, and the $\mathrm{Ni} / \mathrm{BaZrO}_{3}$ catalyst was the most active among the samples investigated. In the $\mathrm{Ni} / \mathrm{AETiO}_{3}$ and $\mathrm{Ni} / \mathrm{AEZrO}_{3}$ series, the trend in the catalytic activity corresponded with that in the basic property. The $\mathrm{NH}_{3}$-TPSR measurement for the $\mathrm{Ni} / \mathrm{AEZrO}_{3}$ catalysts revealed that the nitrogen desorption effectively proceeded over $\mathrm{Ni} / \mathrm{SrZrO}_{3}$ and $\mathrm{Ni} / \mathrm{BaZrO}_{3}$. This promotion effect would be ascribed to the strong basic property of $\mathrm{SrZrO}_{3}$ and $\mathrm{BaZrO}_{3}$ supports, and lead to the high activity of $\mathrm{Ni} / \mathrm{SrZrO}_{3}$ and $\mathrm{Ni} / \mathrm{BaZrO}_{3}$. 


\section{Conflicts of interest}

There are no conflicts to declare.

\section{Acknowledgements}

This work was supported by Council for Science, Technology and Innovation (CSTI), Cross-ministerial Strategic Innovation Promotion Program (SIP), “energy carrier" (Funding agency: JST).

\section{Notes and references}

1 A. J. Appleby, Int. J. Hydrogen Energy, 1994, 19, 175-180.

2 D. K. Ross, Vacuum, 2006, 80, 1084-1089.

3 T. V. Choudhary and D. W. Goodman, Catal. Today, 2002, 77, 65-78.

4 F. Schüth, R. Palkovits, R. Schlögl and D. S. Su, Energy Environ. Sci., 2012, 5, 6278-6289.

5 E. García-Bordejé, S. Armenise and L. Roldán, Catal. Rev., 2014, 56, 220-237.

6 T. E. Bell and L. Torrente-Murciano, Top. Catal., 2016, 59, 1438-1457.

7 S. F. Yin, B. Q. Xu, X. P. Zhou and C. T. Au, Appl. Catal., A, 2004, 277, 1-9.

8 S. Stolbov and T. S. Rahman, J. Chem. Phys., 2005, 123, 204716.

9 X. Duan, G. Qian, C. Fan, Y. Zhu, X. Zhou, D. Chen and W. Yuan, Surf. Sci., 2012, 606, 549-553.

10 X. Duan, J. Ji, G. Qian, C. Fan, Y. Zhu, X. Zhou, D. Chen and W. Yuan, J. Mol. Catal. A: Chem., 2012, 357, 81-86.

11 D. A. Hansgen, D. G. Vlachos and J. G. Chen, Nat. Chem., 2010, 2, 484-489.

12 Z. Ulissi, V. Prasad and D. G. Vlachos, J. Catal., 2011, 281, 339-344.

13 A. Takahashi and T. Fujitani, J. Chem. Eng. Jpn., 2016, 49, 2228.

14 S. F. Yin, Q. H. Zhang, B. Q. Xu, W. X. Zhu, C. F. Ng and C. T. Au, J. Catal., 2004, 224, 384-396.

15 T. V. Choudhary, C. Svadinaragana and D. W. Goodman, Catal. Lett., 2001, 72, 197-201.

16 W. Raróg, Z. Kowalczyk, J. Sentek, D. Składanpwski, D. Szmigiel and J. Zielinski, Appl. Catal., A, 2001, 208, 213216.

17 D. Szmigiel, W. Raróg-Pilecka, E. Miśkiewicz, Z. Kaszkur and Z. Kowalczyk, Appl. Catal., A, 2004, 264, 59-63.

18 S. F. Yin, B. Q. Xu, W. X. Zhu, C. F. Ng, X. P. Zhou and C. T. Au, Catal. Today, 2004, 93-95, 27-38.

19 S. F. Yin, B. Q. Xu, S. J. Wang and C. T. Au, Appl. Catal., A, 2006, 301, 202-210.

20 L. Li, Z. H. Zhu, Z. F. Yan, G. Q. Lu and L. Rintoul, Appl. Catal., A, 2007, 320, 166-172.

21 K. Nagaoka, K. Honda, M. Ibuki, K. Sato and Y. Takita, Chem. Lett., 2010, 39, 918-919.

22 A. Klerke, S. K. Klitgaard and R. Fehrmann, Catal. Lett., 2009, 130, 541-546.
23 W. Raróg-Pilecka, D. Szmigiel, Z. Kowalczyk, S. Jodzis and J. Zielinski, J. Catal., 2003, 218, 465-469.

24 S. J. Wang, S. F. Yin, L. Li, B. Q. Xu, C. F. Ng and C. T. Au, Appl. Catal., B, 2004, 52, 287-299.

25 K. Nagaoka, T. Eboshi, N. Abe, S. Miyahara, K. Honda and K. Sato, Int. J. Hydrogen Energy, 2014, 39, 20731-20735.

26 A. M. Karim, V. Prasad, G. Mpourmpakis, W. W. Lonergan, A. I. Frenkel, J. G. Chen and D. G. Vlachos, J. Am. Chem. Soc., 2009, 131, 12230-12239.

27 F. R. Garciá-Garciá, A. Guerrero-Ruiz and I. RodríguezRamos, Top. Catal., 2009, 52, 758-764.

28 X. K. Li, W. J. Ji, J. Zhao, S. J. Wang and C. T. Au, J. Catal., 2005, 236, 181-189.

29 C. Plana, S. Armenise, A. Monzón and E. G. Bordejé, J. Catal., 2010, 275, 228-235.

30 H. Liu, H. Wang, J. Shen, Y. Sun and Z. Liu, Appl. Catal., A, 2008, 337, 138-147.

31 H. Muroyama, C. Saburi, T. Matsui and K. Eguchi, Appl. Catal., A, 2012, 443-444, 119-124.

32 A. M. Karim, V. Prasad, G. Mpourmpakis, W. W. Lonergan, A. I. Frenkel, J. G. Chen and D. G. Vlachos, J. Am. Chem. Soc., 2009, 131, 12230-12239.

33 J. Zhang, H. Xu, X. Jin, Q. Ge and W. Li, Appl. Catal., A, 2005, 290, 87-96.

34 W. Zheng, J. Zhang, Q. Ge, H. Xu and W. Li, Appl. Catal., B, 2008, 80, 98-105.

35 K. Okura, T. Okanishi, H. Muroyama, T. Matsui and K. Eguchi, Appl. Catal., A, 2015, 505, 77-85.

36 K. Okura, T. Okanishi, H. Muroyama, T. Matsui and K. Eguchi, ChemCatChem, 2016, 8, 2988-2995.

37 K. Okura, T. Okanishi, H. Muroyama, T. Matsui and K. Eguchi, RSC Adv., 2016, 6, 85142-85148.

38 Q. F. Deng, H. Zhang, X. X. Hou, T. Z. Ren and Z. Y. Yuan, Int. J. Hydrogen Energy, 2012, 37, 15901-15907.

39 H. Zhang, Y. A. Alhamed, Y. Kojima, A. A. Al-Zahrani, H. Miyaoka and L. A. Petrov, Int. J. Hydrogen Energy, 2014, 39, 277-287.

40 Ł. Czekajło and Z. Lendzion-Bielun, Chem. Eng. J., 2016, 289, 254-260.

41 S. Podila, H. Dris, S. F. Zaman, Y. A. Alhamed, A. A. AlZahrani, M. A. Daous and L. A. Petrov, J. Mol. Catal. A: Chem., 2016, 414, 130-139.

42 S. Podila, Y. A. Alhamed, A. A. AlZahrani, M. A. Daous and L. A. Petrov, Int. J. Hydrogen Energy, 2015, 40, 15411-15422.

43 R. Pelka, I. Moszyńska and W. Arabczyk, Catal. Lett., 2009, 128, 72-76.

44 B. Lorenzut, T. Montini, M. Bevilacqua and P. Fornasiero, Appl. Catal., B, 2012, 125, 409-417.

45 S. B. Simonsen, D. Chakraborty, I. Chorkendorff and S. Dahl, Appl. Catal., A, 2012, 447-448, 22-31.

46 A. S. Chellappa, C. M. Fischer and W. J. Thomson, Appl. Catal., A, 2002, 227, 231-240.

47 W. Zheng, T. P. Cotter, P. Kaghazchi, T. Jacob, B. Frank, K. Schlichte, W. Zhang, D. S. Su, F. Schüth and R. Schlögl, J. Am. Chem. Soc., 2013, 135, 3458-3464.

48 C. Liang, W. Li, Z. Wei, Q. Xin and C. Li, Ind. Eng. Chem. Res., 2000, 39, 3694-3697. 
49 A. Srifa, K. Okura, T. Okanishi, H. Muroyama, T. Matsui and K. Eguchi, Catal. Sci. Technol., 2016, 6, 7495-7504.

50 S. Podila, S. F. Zaman, H. Driss, Y. A. Alhamed, A. A. AlZahrani and L. A. Petrov, Catal. Sci. Technol., 2016, 6, 1496-1506.

51 D. V. Leybo, A. N. Baiguzhina, D. S. Muratov, D. I. Arkhipov, E. A. Kolesnikov, V. V. Levina, N. I. Kosova and D. V. Kuznetsov, Int. J. Hydrogen Energy, 2016, 41, 3854-3860.

52 Z. Zhao, H. Zou and W. Lin, J. Rare Earths, 2013, 31, 247-250. 53 A. Srifa, K. Okura, T. Okanishi, H. Muroyama, T. Matsui and K. Eguchi, Appl. Catal., B, 2017, 218, 1-8.

54 S. S. Pansare, W. Torres and J. G. Goodwin Jr, Catal. Commun., 2007, 8, 649-654.
55 J. G. Choi, J. Catal., 1999, 182, 104-116.

56 Z. Wang, B. Liu and J. Lin, Appl. Catal., A, 2013, 458, 130-136.

57 K. Urasaki, Y. Sekine, S. Kawabe, E. Kikuchi and M. Matsukata, Appl. Catal., A, 2005, 286, 23-29.

58 K. Urasaki, K. Tokunaga, Y. Sekine, S. Kawabe, M. Matsukata and E. Kikuchi, Catal. Commun., 2008, 9, 600-604.

59 S. J. Tauster, S. C. Fung and R. L. Garten, J. Am. Chem. Soc., 1978, 100, 170-175.

60 Z. Wang, J. Lin, R. Wang and K. Wei, Catal. Commun., 2013, 32, 11-14.

61 F. Hayashi, Y. Toda, Y. Kanie, M. Kitano, Y. Inoue, T. Yokoyama, M. Hara and H. Hosono, Chem. Sci., 2013, 4, 3124-3130. 